\title{
Whither Roman Archaeology? Or Wither Roman Archaeology! A London Perspective
}

\author{
Mark Hassall \\ Reader in Roman Archaeology \\ Institute of Archaeology, UCL
}

\begin{abstract}
With his approaching retirement from the Institute of Archaeology (IoA) at the end of this academic year, Mark Hassall was invited to write the Forum on the topic of Roman archaeology - his views on the state of the discipline, as well as its future direction within the context of teaching and research in London and within the UK.
\end{abstract}

\section{Roman Archaeology - Is it Really Archaeology?}

One of the inescapable issues regarding Roman archaeology is that it deals with a historically-documented period and so, it might be argued, isn't really archaeology at all! In other words, real archaeology deals with artefacts, not texts (but surely cylinder seals and Roman inscriptions are artefacts?). To this I would reply that if we cut out historically-documented cultures as the object of the proper study of our discipline, we would cut out everything from Mesopotamia to the Maya; from Egypt to China. As archaeologists, if we ignore the written word when we look at these past civilisations, we are like tourists visiting a foreign country (the Past) with their fingers in their ears, just as historians who ignore the material remains of the civilisations that they study - the 'stuff of archaeology' - are like others with their hands over their eyes. If we are genuinely interested in the past, then we should explore all the avenues at our disposal for a better understanding of it. As Michael Coe put it: "Imagine someone calling himself an Egyptologist who couldn't read a hieroglyphic inscription, or a Sinologist tongue-tied in Chinese! How can illiterate scholars pretend to study a literate civilisation?" (Coe 1992: 274).

\section{Roman Archaeology Isn't Politically Correct}

Roman archaeology, until recently, has dealt with an imperialist regime with whom latter day Imperialists and Fascists in western Europe have identified, and we don't like people like that (cf. Hingley 2000; James 2002)! Bad luck. Either one is interested in the past or not. If you cut out Rome because you don't like its imperialist connotations, you are cutting out a huge and significant chunk of humanity's past, especially when one considers the area encompassed by the Roman empire - western Europe, the Middle East and the Mahgreb. One must also consider the length of time that it lasted: in the narrow sense, some 500 years from the battle of Actium in $31 \mathrm{BC}$ to the fall of the western empire with the deposition of Romulus Augustulus in AD 476; or in the wider sense, well over 2000 years from the traditional founding of Rome in $753 \mathrm{BC}$ to the fall of Constantinople in AD 1453. Consider, too, the influence that it had on subsequent cultures - think of architecture, from the Renaissance to the $20^{\text {th }}$ century. We at UCL should be more aware than most of neoclassical architecture, even if our masters in planning seem not to appreciate it, judging by the siting of the new UCL Hospital Tower. If this had been located at the Tottenham Court Road end of the site it would not 
visually wreck the front neoclassical quadrangle in the way that it now does. Or consider language: the Romance languages include, besides Romanian, French and Italian, such global languages as Spanish and Portuguese. There has also been a huge influence - through French - on another world language: English. Even the alphabet that we take for granted is Roman. Politically too, with the rise of the European Union, Rome has a new contemporary relevance, for in a sense it could be regarded as the forerunner of the European Union. Rome is indeed a world civilisation. We may not like Rome - that is our privilege - but we cannot pretend that it doesn't exist or that it is not relevant in a way that few other ancient civilisations can claim to be.

Does Size Matter? The Current Situation at the Institute of Archaeology, UCL

I recently interviewed a prospective postgraduate student. She came from the United States and was interested in doing research at the IoA in the field of Roman archaeology. I pointed out to her that if she did the Master's in Research Methods (MRes) with us, I would have retired by the end of the next academic year, so I wouldn't actually be here to act as a supervisor; therefore, there wasn't much point in discussing the details of potential research topics with me. Nevertheless, Roman archaeology at the IoA would be left in the capable hands of Kris Lockyear and Jeremy Tanner, who together represent 1.5 posts (Jeremy counts as half a post since he also covers Greek archaeology). Greek archaeology here is already in this position -1.5 posts (represented by Alan Johnston and the other half by Jeremy Tanner). In other words, between them, Greek and Roman archaeology will be covered by just three posts, and none of these will have professorial status. I felt, in all honesty, that I should suggest to our American applicant that she should at least look at other universities. As a high fee-paying applicant she will be in a strong position with departmental admissions boards. (Since writing these words, I am glad to say that she has decided to apply to the IoA after all, but a second applicant in Roman archaeology has subsequently been rejected because there will not be a suitable supervisor.)

I then recalled that I had just written three references for ex-students of mine for two posts in Roman archaeology that had been advertised at Oxford. There are two chairs at Oxford - one of Classical Archaeology and Art, and one of the Archaeology of the Roman Empire. The same situation existed at the IoA when I first came here as a postgraduate student in the early 1960s, and remained the case down to 1992 with the retirement of Nicholas Coldstream, Yates Professor of Classical Archaeology. The first holder of the Yates Chair in the 1860s was Sir Charles Newton, for whom I have a soft spot - he directed excavations at Knidos in southwest Turkey where I excavated over 30 years ago. In 1992, the Yates Chair in effect ceased to exist. In that year, John Wilkes, formerly Professor of the Archaeology of the Roman Provinces at the IoA, succeeded Nicholas Coldstream, but the post was then described as the Chair in Greek and Roman Archaeology - a subtle but significant change. A rose (you, John) by any other name would certainly smell as sweet, but this did not alter the fact that we had lost the Chair of Classical Archaeology, for John basically continued to teach the same course in provincial Roman archaeology as before. When John Wilkes retired in 2001, we lost the Chair in the Archaeology of the Roman Provinces as well. 
The Other Side of the Forest: Archaeology Departments Elsewhere

Besides the two chairs at Oxford mentioned above, there are also the Readership in Classical Archaeology and the University Lectureship in Classical Art (combined with the curatorship of the Beasley Archive). To these four posts, one should add the two new posts that were advertised: a University Lectureship in Roman Archaeology, and a Research Assistant to the Professor of the Archaeology of the Roman Empire, a post which will include some teaching. So Oxford will have six posts in Greek and Roman archaeology compared to, when I leave at the end of 2004/5, the IoA's three.

Are Oxford's six posts over-generous provision for a subject whose importance - along with Classics in general - has been so grossly favoured in the past? Surely the days are long gone when the Colonial Office sent out viceroys and governors to lord it over the lesser breeds, armed with only the maxim gun and a knowledge of Greek irregular verbs, and thank goodness for that! Yes, Oxford - home of lost causes - what can you expect? So let us look at Roman archaeology elsewhere, at Leicester for example where there is a chair (David Mattingly), a senior lectureship (Simon James, ex-IoA) and two shared posts; or at Reading: a chair (Mike Fulford), two lecturers and a shared post. Even Winchester, one of the newest of the new universities, has a chair in Roman archaeology, occupied by the admirable Tony King (ex-IoA), supported by the equivalent of half a post.

\section{Roman Archaeology at the IoA - The Future}

I believe that Roman - and Greek - archaeology at the IoA should be taught on at least a comparable level to Oxford - with an establishment of say, four as an absolute minimum: Chairs of Roman and Greek Archaeology and two lectureships, one Greek and one Roman. Depending on how you look at it, this would put Classical archaeology/Greek and Roman archaeology on the same level with Egyptology at the IoA, with two professors and two lecturers. Or, if you take Roman archaeology as a subject in its own right, half the establishment of Egyptology. It is not that I begrudge Egyptology its healthy establishment; far from it. Egyptology at the IoA is one of our most popular undergraduate degrees, and the staff are fully stretched. However, if you have a strong coverage in an archaeological specialism, whether Egyptology or Roman archaeology, it should attract good students and, as outlined in the first section of this paper, we are currently losing out on numbers of postgraduate students, in Roman archaeology at least. Some idea of potential numbers at the undergraduate level can be gauged by the 30 students (a number of whom are intercollegiate) who enrolled for the course on Roman Art and Architecture in 2003/4. I would like to see this potential being built upon, and the Chair of Roman Archaeology revived and held by a Classical archaeologist in the mould of Donald Strong who taught here as the charismatic professor from 19681973 (Hassall 1974). Despite his all too short tenure of the chair, a surprising number of his pupils now hold senior posts in Britain and abroad - Oxford (the Ashmolean), London, Malta, Cyprus, Adelaide... If he had lived, the course of Roman (Classical) archaeology in London, if not in England, might have been very different.

The second post, I would like to see devoted to 'provincial' rather than 'classical' Roman archaeology, the holder perhaps having a specialism such as Richard Reece had 
(and Kris Lockyear has) in Roman numismatics, or as I have in Roman epigraphy. I would argue for a minimum of two posts in Roman archaeology, although for a period from the arrival of Kris Lockyear in 1996 to the retirement of Richard Reece in 1999 there were actually 4.5 posts! Whatever the actual final number, I believe that there should be a viable Roman presence at the IoA because of:

1. The intrinsic importance of the subject in comparison with other world cultures (see above).

2. The unique advantages enjoyed by London over other British universities for the study of Classical archaeology through the presence of the British Museum and its collections, the Societies for Hellenic and Roman Studies, and the Institute of Classical Studies, all three located in Senate House, University of London. With the right establishment and the right people filling the posts, we could be the premier department for Classical archaeology in the country. And so we should be.

3. Practical considerations. The majority of students who come to the IoA as undergraduates will come from this country, and if they succeed in making a career, it will be in this country whether with archaeological units, in the 'heritage industry' or in academic archaeology. But there are other students who do not intend to make a career in archaeology. For these in particular, it is surely desirable to offer a series of options on a global basis. This is why the arrival of dedicated specialists in Chinese archaeology at the Institute is such a welcome development. But let us not delude ourselves: the demand for experts in Chinese archaeology in this country is likely to remain small! However, of course, this is to miss the point. The new International Centre for Chinese Heritage and Archaeology located at the IoA has a dual role, and is not just intended for home students, but to act as a base for Chinese students studying such disciplines as archaeobotany, archeometallurgy and public archaeology (Ucko $2001 / 2 ; 2002 / 3 ; 2003 / 4)$. This brings us to the general - and very important - question of overseas recruitment, important to us not only because the IoA has and should retain an international reputation, but also important to us financially. But what is our natural constituency when it comes to overseas students? And here, dare I state the obvious. If I, as a European, wanted to study New World archaeology, then I would cross the Atlantic. And if I wanted to specialise in Chinese archaeology - rather than just take one or two courses - I would go to China. But if I were from anywhere outside Europe and wished to study European archaeology (including Roman archaeology), I would, ideally, study it in Europe, perhaps Britain.

\section{Some Conclusions}

In conclusion, however desirable it is that we maintain a good global coverage in the courses offered at the IoA, it should not be at the expense of British archaeology or perhaps, better, British archaeology in its European context - including Roman archaeology - as that is, after all, where the jobs are. And as for Classical archaeology - whether Greek or Roman - London is in a unique position for the study of this subject, and our catchment should be truly international. Here, the International Centre for Chinese Heritage and Archaeology, sponsored not only by ourselves, but also the 
School of Oriental and African Studies and the University of Beijing, perhaps provides a model. There is a wealth of expertise in London - at UCL, the British Museum, the Institute of Classical Studies, King's College, the Courtauld and Warburg Institutes, as well as Royal Holloway - and we should be acting, not in competition with these, but in concert to make London the centre of excellence in Classical archaeology that it deserves to be.

In view of all this, it is good to report that the word on the street is that there is a general recognition among those who matter that the downward trend from the high point of 4.5 posts in Roman archaeology in the late 1990 s, to 1.5 posts on my retirement has gone far enough and is one that should be and will be reversed!

\section{References}

Coe, M. D. 1992. Breaking the Maya Code. London: Ucko, P. J. 2001/2. Some Highlights of the 2001/2002 Thames and Hudson. Academic Year. Archaeology International 5, 3 .

Hassall, M. 1974. Professor Donald Strong President. Journal of the British Archaeological Ucko, P. J. 2002/3. Some Highlights of the 2002/2003 Association Third Series $37,1$. Academic Year. Archaeology International 6, 3 .

Hingley, R. 2000. Roman Officers and English Gentleman. London: Routledge.

Ucko, P. J. 2003/4. Some Highlights of the 2003/2004 Academic Year. Archaeology Interna-

James, S. T. 2002. Writing the Roman Legions: The Development and Future of Roman Miltional 7, 3 .

itary Studies in Britain. Archaeological Journal 159, 1-58. 